\title{
Establishment and characterization of a highly immunogenic human renal carcinoma cell line
}

\author{
CLELIA PRATTICHIZZO $^{1 *}$, MARGHERITA GIGANTE ${ }^{2 *}$, PAOLA PONTRELLI $^{2}$, ALESSANDRO STELLA $^{4}$, \\ MARIA TERESA ROCCHETTI ${ }^{2}$, MADDALENA GIGANTE ${ }^{1}$, EUGENIO MAIORANO ${ }^{5}$, WOLFGANG HERR ${ }^{6}$, \\ MICHELE BATTAGLIA $^{3}$, LORETO GESUALDO ${ }^{2}$ and ELENA RANIERI ${ }^{1}$ \\ ${ }^{1}$ Department of Medical and Surgical Sciences, Section of Clinical Pathology, University of Foggia, Foggia; \\ ${ }^{2}$ Department of Emergency and Organ Transplantation, Section of Nephrology, ${ }^{3}$ Section of Urology, ${ }^{4}$ Medical Genetics Unit, \\ Department of Biomedicine in Childhood, and ${ }^{5}$ Department of Pathological Anatomy, University of Bari 'Aldo Moro', \\ Bari, Italy; ${ }^{6}$ Department of Medicine III, Johannes Gutenberg-University Mainz, Mainz, Germany
}

Received October 12, 2015; Accepted December 2, 2015

DOI: 10.3892/ijo.2016.3544

\begin{abstract}
Renal cell carcinoma (RCC) is the most common kidney cancer, and accounts for $3 \%$ of all adult malignancies. RCC has proven refractory to conventional treatment modalities but appears to be the only histological form that shows any consistent response to immunotherapeutic approaches. The development of a clinically effective vaccine remains a major strategic target for devising active specific immunotherapy in RCC. We aimed to identify a highly immunogenic antigenic format for immunotherapeutic approaches, so as to boost immune responses in RCC patients. We established and cloned an immunogenic cell line, RCC85\#21 named Elthem, which was derived from a non-aggressive and non-metastatic clear cell carcinoma. The cell line characterization was performed by genomics (real-time PCR, genome instability), proteomics (two dimensional electrophoresis, mass spectro-metry) and immunological analysis (mixed lymphocytes tumor cell cultures). Real-time PCR confirmed the RCC85\#21 cell expression of tumor antigens and cytokine genes. No difference in microsatellite instability (MSI) in RCC85\#21 cell line was found as compared to control, loss of heterozygosity was
\end{abstract}

Correspondence to: Dr Elena Ranieri, Department of Medical and Surgical Sciences, Section of Clinical Pathology, University of Foggia, Viale Luigi Pinto 1, I-71100 Foggia, Italy

E-mail: elena.ranieri@unifg.it

*Contributed equally

Abbreviations: RCC, renal cell carcinoma; TAAs, tumor associated antigens; MSI, microsatellite instability; LOH, loss of heterozygosity; 2-DE, two-dimensional electrophoresis; MALDI/TOF, matrix absorption laser desorption ionization/time of flight; MLTC, mixed lymphocytes tumor cell cultures

Key words: renal cancer cell line, immunogenic antigenic format, cell proteome observed in the RCC85\#21 clone, but not in the renal cancer cell lines from which it was generated. The image analysis of RCC $85 \# 21$ by two-dimensional gels showed $700 \pm 26$ spots and 119 spots were identified by mass spectrometry analysis. RCC85\#21 promoted a significant RCC-specific T cells activation by exhibiting a cytotoxic phenotype after mixed lymphocyte and tumor cell cultures. $\mathrm{CD}^{+} \mathrm{T}$ cells isolated from RCC patients displayed an elevated reactivity against RCC85\#21 and efficiently lysed the RCC85\#21 clone. The RCC85\#21 immunogenic cell line will be suitable for immune stimulation. The identification of novel tumor associated antigens will allow the evaluation of the immune response in vitro and, subsequently, in vivo paving the way for new immunotherapeutic strategies in the RCC setting.

\section{Introduction}

Renal cell carcinoma (RCC) is the most common kidney cancer type, accounting for $3 \%$ of all adult malignancies in western countries $(1,2)$. Radical nephrectomy can be curative in early stage disease, but $30 \%$ of patients present with advanced disease, including locally invasive or metastatic RCC at the time of diagnosis, which seems to be resistant to cytotoxic chemotherapies, hormone therapies and radiotherapies $(3,4)$. The most common histological type of RCC is renal clear cell carcinoma (CC), that accounts for $~ 70-80 \%$ of all renal neoplasms and appears to be the only histological subtype that shows any consistent response to immunotherapeutic approaches (5-7). Cytokine-based immunotherapy, such as interleukin (IL)-2 and interferon (IFN)- $\alpha$, either as single agents or in combination (8), has previously been adopted in the adjuvant setting of RCC, but produced only occasional benefits. The limited success indicates the potential value of optimizing cell-based immunotherapy for RCC with the aim of increasing the number of durable responses, as has already been done with some success in melanoma, in which this approach resulted highly effective for metastatic patients refractory to other treatments (9). One important aspect of cell-based immunotherapy is the in vitro generation of tumor- 
reactive $\mathrm{T}$ cells that can exert an antitumor activity in vivo. To achieve this aim, it is necessary to select and expand tumorspecific $\mathrm{T}$ cells after culture with highly immunogenic tumor cell lines, or identify new RCC tumor-associated antigens (TAAs). Recent progress in proteomic technologies, such as the development of quantitative proteomic methods, highresolution, high-speed and high-sensitivity mass spectrometry, has opened up new avenues for the discovery of TAAs. Studies of global protein expression in human tumors using proteomic technologies have led to the identification of various biomarkers that will potentially be useful in identifying cancer in different organs, including the liver, prostate, breast, bladder, colon, stomach, lung and ovaries (10-18). Several groups have studied protein expression in RCC cell lines with twodimensional gel electrophoresis technology in combination with mass spectrometry (MS) to detect RCC markers (19-21) but in the present study, for the first time, we have applied system biology to characterize an immunogenic cell line by means of genomic and proteomic approaches. Proteomics is a powerful tool for screening and identifying novel TAAs that could be used to devise prospective cell-based vaccines for RCC patients. Changes in TAAs expression levels may also be effectively monitored using two dimensional electrophoresis/ matrix absorption laser desorption ionization/time of flight/ mass spectrometry (2-DE/MALDI/TOF/MS) analysis, that allows rapid and systematic analysis of thousands of proteins.

\section{Materials and methods}

Ethics statement. The cell line was generated from primary kidney tissue explants, after obtaining written informed consent. The protocol was approved by ethics commission of the medical faculty of the University Hospital of Bari, Italy.

Isolation and cloning of RCC85\#21 cell line. The primary tumor was histological type grade I according to the Fuhrman et al classification (22), non-aggressive and did not invade the renal artery or vena cava. The tissue was composed mainly of clear cells with an alveolar/tubular arrangement. The tumoral tissue was minced and digested using an enzymatic cocktail, as previously described (23). The cellular suspension was filtered $(100 \mu \mathrm{m})$, washed and centrifuged $500 \mu \mathrm{g}$ for $10 \mathrm{~min}$. The pellet was resuspended in AR5 medium [RPMI1640 medium supplemented with $20 \%$ fetal bovine serum (FBS), $20 \mu \mathrm{g} / \mathrm{ml}$ insulin, $10 \mu \mathrm{g} / \mathrm{ml}$ transferrin, $25 \mathrm{nM}$ sodium selenite, $50 \mathrm{nM}$ hydrocortisone, $1 \mathrm{ng} / \mathrm{ml}$ epidermal growth factor, $10 \mu \mathrm{M}$ ethanolamine, $10 \mu \mathrm{M}$ phosphorylethanolamine, $100 \mathrm{pM}$ triiodothyronine, $2 \mathrm{mg} / \mathrm{ml}$ bovine serum albumin, $10 \mathrm{mM}$ HEPES buffer, $2 \mathrm{mM}$ L-glutamine and $0.5 \mathrm{mM}$ sodium pyruvate] and incubated for 5 days. In the subsequent step, the cells were resuspended in basal medium composed of RPMI medium supplemented with $20 \%$ FBS, 2 mM L-glutamine, $100 \mathrm{IU} / \mathrm{ml}$ penicillin, $100 \mathrm{mg} / \mathrm{ml}$ streptomycin and $10 \mathrm{mM}$ HEPES, and placed in culture flasks incubated at $37^{\circ} \mathrm{C}$ and $5 \% \mathrm{CO}_{2}$. The RCC85 cell line was cloned using the 'limiting dilution' technique: $1 \times 10^{5}$ tumor cells at passage 39 were diluted in basal medium and plated in 96-well plates; $1 \times 10^{4}$ 'feeder cells' (NIH 3T3) irradiated with 10,000 rad were added to each well to ensure the viability and proliferation of tumor cells. After $16 \mathrm{~h}$ of incubation the cells were diluted to obtain 1-10 cells per well. After one week, cell clones presenting cell proliferation were identified by microscopic observation, and the tumor cells were expanded by transferring the plates from 48- and 24-wells. The final result was the isolation of a stabilized, immunogenic clone of renal tumor cells. Epstein-Barr virus (EBV)-transformed lymphoblastoid cell lines (EBV-LCL) were also generated from patient RCC85 PBMC using the B95.8 (type 1) virus isolate.

Immunocytochemistry. Samples taken from cell culture flasks were retained in PreservCyt ${ }^{\mathrm{TM}}$. Subsequently, cytological preparations were obtained in monolayer apparatus with ThinPrep, the first of which was colored by Papanicolaou staining. The others were used for immunocytochemical staining, performed with the avidin-biotin-peroxidase technique in an automatic immunostainer (DakoCytomation, Carpinteria, CA, USA), using the following primary antibodies: cytokeratin AE1/AE3 (dilution 1/5), cytokeratin 18 (dilution 1/2), cytokeratin 19 (dilution 1/100), epithelial membrane antigen (EMA) (dilution 1/100), Ki-67 (dilution 1/100), mitochondria (dilution 1/75), vimentin (dilution 1/2) and the detection system LSAB Plus (DakoCytomation). The sections were incubated with primary antibodies for $16 \mathrm{~h}$ at $4{ }^{\circ} \mathrm{C}$ and then with biotinylated secondary antibodies and avidin-peroxidase for $30 \mathrm{~min}$ at $37^{\circ} \mathrm{C}$. Detection was done with diaminobenzidine chromogen (DAB) for $20 \mathrm{~min}$ at $20^{\circ} \mathrm{C}$ and nuclear contrast was obtained by immersion for $2 \mathrm{~min}$ in Meyer's hematoxylin. The sections were finally mounted with glycerine and special coverslips. At least 3 experiment for each sample were performed.

Real-time PCR. Total RNA was isolated from RCC85\#21, HeLa (human cervical cancer cells) and HK2 (normal human kidney cells) cell lines with the TRIzol ${ }^{\circledR}$ reagent (Invitrogen, Carlsbad, CA, USA) and cDNA was synthesized with the High Capacity cDNA Reverse Transcription kit (Life Technologies Europe BV, The Netherlands) according to the manufacturer's instructions. The expression levels of the following tumor antigen and inflammatory antigen/cytokine genes were analysed by real-time PCR on a 7500 Fast Real-Time PCR system (Life Technologies): telomerase reverse transcriptase (TERT), ribosomal protein SA or laminin receptor 1 (RPSA alias OFA/ iLRP), carboxylesterase 1 (CES1) and interleukin-6 (IL6). Real-time PCR reactions were performed using the TaqMan Universal PCR Master Mix and the following TaqMan Gene Expression assays (Life Technologies): Hs00972656_m1 (TERT), Hs01080364_m1 (RPSA), Hs00275607_m1 (CES1) and Hs00985639_m1 (IL-6). Each assay contains two unlabeled PCR primers (each final concentration being $900 \mathrm{nM}$ ) and one FAM dye labeled TaqMan MGB probe (final concentration $250 \mathrm{nM}$ ). Human ACTB ( $\beta$ actin) was used as endogenous control (VIC/MGB Probe, Life Technologies). Negative controls (samples without reverse transcriptase) were included. Quantitative values were obtained from the Ct (threshold cycle) data determined using default threshold settings. Gene expression data were normalized to human $\operatorname{ACTB}(\beta$ actin) and the relative quantification (RQ) was calculated with the $2-\Delta \Delta \mathrm{Ct}$ method. The data are presented as relative quantity (RQ) of target genes, normalized with respect to ACTB and the calibrator sample (HK2). At least 3 experiment for each sample were performed. 
Table I. Primer set for genetics instability.

\begin{tabular}{llc}
\hline Primer sequences & No. of GDB & Size (kbp) \\
\hline BAT-25 & & 120 \\
$\quad$ Forward: 5'-TCGCCTCCAAGAATGTAAGT-3' & 9834508 & \\
$\quad$ Reverse: 5'-TCTGCATTTTAACTATGGCTC-3' & U63834 & \\
BAT-26 & & 116 \\
$\quad$ Forward: 5'-TGACTACTTTTGACTTCAGCC-3' & 9834505 & \\
$\quad$ Reverse: 5'-AACCATTCAACATTTTTAACCC-3' & L47575 & \\
D5S346 (DP1) & 181171 & \\
$\quad$ Forward: 5'-ACTCACTCTAGTGATAAATCGGG-3' & & $197-227$ \\
$\quad$ Reverse: 5'-AGCAGATAAGACAGTATTACTAGTT-3' & & \\
D2S123 & & 187953 \\
$\quad$ Forward: 5'-AAACAGGATGCCTGCCTTTA-3' & & \\
$\quad$ Reverse: 5'-GGACTTTCCACCTATGGGAC-3' & & \\
D17S250 & & \\
$\quad$ Forward: 5'-GGAAGAATCAAATAGACAAT-3' & X54562 \\
$\quad$ Reverse: 5'-GCTGGCCATATATATATTTAAACC-3' & & \\
\hline
\end{tabular}

The sequences of primers used, the number of GDB/Genebanks and the size of amplified products.

Genetics instability. Genomic DNA was extracted from RCC cell lines and lymphocytes with the Blood and Cell Midi kit (Qiagen, Milan, Italy), according to the manufacturer's instructions. Then, DNA samples were evaluated for microsatellite instability (MSI) and loss of heterozygosity $(\mathrm{LOH})$ by polymerase chain reaction (PCR) and a panel of 5 microsatellite markers: BAT25 and BAT26 (mononucleotide repeat), D2S123, D5S346 and D17S250 (dinucleotide repeat) (23). PCR reactions were performed in a final volume of $15 \mu 1$ with $50 \mathrm{ng}$ of genomic DNA and using the following reaction profile: $2 \mathrm{~min}$ initial denaturation at $95^{\circ} \mathrm{C}$ followed by $95^{\circ} \mathrm{C} \mathrm{x}$ $20 \mathrm{sec}, 55^{\circ} \mathrm{C} \mathrm{x} 20 \mathrm{sec}, 72^{\circ} \mathrm{C}$ x $20 \mathrm{sec}$ for 30 cycles and $5^{\prime}$ of final extension at $72^{\circ} \mathrm{C}$. The primer set sequences used, the number of GDB/Genebanks and the size of amplified products are shown in Table I. The microsatellite analysis was carried out by SSCP (single-strand conformation polymorphism) using a vertical electrophoresis system in polyacrylamide gel at $10 \%$ (acrylamide/bis acrylamide 19:1) containing $8 \mathrm{M}$ urea. The electrophoretic run was performed at $56^{\circ} \mathrm{C}$ using the D-GENE System (Bio-Rad, Hercules, CA, USA). Silver staining for visualization of the bands was carried out with $0.2 \%$ silver nitrate. Positive MSI results were confirmed by repetition in independent PCR reactions at least twice. Allelic loss (LOH) was determined in cases where one of the normal alleles for a given marker was missing.

Two-dimensional electrophoresis (2DE). RCC85\#21 clones were cultured until confluence at the 40th passage. Cells, $3.5 \times 10^{6}$, were resuspended in sample buffer $(8 \mathrm{M}$ urea, 4\% CHAPS, $40 \mathrm{mM}$ Tris-base, $65 \mathrm{mM}$ DTT, and a trace amount of bromophenol blue). The total protein concentration was measured by colorimetric assay based on the Bradford dye-binding method (Bio-Rad protein assay) and samples were stored at $-80^{\circ} \mathrm{C}$ until use. Isoelectrofocusing was carried out using a 13-cm immobiline DryStrip of $\mathrm{pH}$ 3.0-10.0 non-linear range. The IPG strips were rehydrated for 8-10 h at room temperature with $250 \mathrm{ml}$ rehydration solution $[8 \mathrm{M}$ urea, $2 \%$ (w/v) CHAPS, 0.5\% ampholine $\mathrm{pH} 3.0-10.0,18 \mathrm{mM}$ DTT, $0.002 \%(w / v)$ bromophenol blue]. Proteins (60 mg) were loaded onto rehydrated IPG strips for analysis and $1 \mathrm{~g}$ protein was loaded for preparative 2-D PAGE. IEF of the proteins was performed at $40 \mathrm{kkVolt}$ hour total produced by overnight run. After IEF, IPG strips were incubated at room temperature for $15 \mathrm{~min}$ in $130 \mathrm{mM}$ DTT equilibration buffer [ $75 \mathrm{mM}$ Tris- $\mathrm{HCl}$, $\mathrm{pH} 8.8 ; 6 \mathrm{M}$ urea; 30\% (v/v) glycerol 87\%; $2 \%$ (w/v) SDS; $0.002 \%$ bromophenol blue, then for $15 \mathrm{~min}$ in $270 \mathrm{mM}$ IAA equilibration buffer]. The second dimension was carried out on in-house polyacrylamide/PDA $(12.5 \% \mathrm{~T} / 2.6 \% \mathrm{C})$ lab gels in SDS-PAGE running buffer. Analytical 2-DE gels were stained with the PlusOne silver stain kit. Preparative 2-DE gels were stained with $0.05 \%$ (w/v) Coomassie Brilliant Blue R-250. Stained gels were scanned with a flat-bed ImageScanner (Amersham Pharmacia Biotech) to generate digital images. The 2-DE gel images were analyzed using Image Master 2D Platinum software (Amersham Biosciences, Uppsala, Sweden). At least 3 replicate gels for each sample were performed.

MALDI-TOF/MS analysis. The protein spots on 2-DE gels were manually excised, and underwent in-gel tryptic digestion by an adaptation of the procedure by Shevchenko et al (25). Peptide digests were analysed using a MALDI-TOF/MS (Autoflex II, Bruker Daltonics, Bremen, Germany) instrument. Prior to mass spectrometry analysis, the tryptic peptide mixture was desalted and concentrated using ZipTip ${ }^{\circledR}$ Pipette Tips packed with $\mathrm{C}_{18}$ resin (Millipore, USA). The peptides were eluted from ZipTip directly onto the Prespotted Anchor Chip ${ }^{\mathrm{TM}}$ (PAC, 
Bruker Daltonics) a MALDI sample carrier with spotted matrix ( $\alpha$-cyano-4-hydroxycinnaminic acid) positioned beside the pre-spotted calibration point. The MALDI mass spectra were acquired on an Autoflex II mass spectrometer equipped with a 337-nm nitrogen laser. All spectra were collected in reflecting mode with a delayed extraction time of $110 \mathrm{~ns}$, except for PSD spectra which were collected without postionization delayed extraction. Post source decay (PSD) spectra were externally calibrated using abundant fragment ion peaks derived from angiotensin I, ACTH 1-17 and ACTH 18-39. The selection of precursor ions for PSD analysis was done with an ion gate at a resolution of $\sim 100$ FWHM (full width half the maximum). A total of 300-400 laser shots at a $50-\mathrm{Hz}$ repetition rate were collected over different areas of the sample/ matrix spot to generate averaged precursor ion and PSD mass spectra. Mass spectra were acquired from each sample in the $400-3500-\mathrm{m} / \mathrm{z}$ range. All mass values are reported as monoisotopic masses. The program used to create the 'peak list' from the raw acquired data was Flex Analysis 2.1 with the default parameters. Protein identification was achieved by database search via Biotools 2.2 and MASCOT search algorithm (http:// www.matrix.science.com) against the MSDB, NCBInr and Swissprot databases using the following parameters: Homo sapiens as taxonomic category, trypsin as enzyme, carbamidomethyl as fixed modification for cysteine residues, oxidation of methionine as variable modification, and one missing cleavage and $100 \mathrm{ppm}$ as mass tolerance for the monoisotopic peptide masses.

Immunophenotypic analysis. The following fluorescein isothiocyanate (FITC)-conjugated or phycoerythrin (PE)conjugated $\mathrm{mAbs}$ were used for immunofluorescent staining of the RCC85\#21 cell line: anti-HLA class I, anti-HLA-DR, anti-CD54, anti-CD80, anti-CD40 and anti-CD86 (BD Pharmingen). In order to stimulate the expression of costimulatory markers, RCC85\#21 cells were incubated with IFN- $\gamma$ for $48 \mathrm{~h}$ at the concentration of $500 \mathrm{IU} / \mathrm{ml}$. Cells were washed and resuspended in FACS buffer (phosphate-buffered saline $\mathrm{pH} 7.2,0.2 \%$ bovine serum albumin, and $0.02 \%$ sodium azide) and incubated with fluorochrome-conjugated $\mathrm{mAbs}$ for $15 \mathrm{~min}$ at $4^{\circ} \mathrm{C}$, then washed with the same buffer before flow cytometric analysis. Data were acquired using an EPICS XL flow cytometer (Beckman Coulter, USA) and analysed using WinMDI Version 2.8 software. The area of positivity was determined using an isotype-matched $\mathrm{mAb}$, and a total of $10^{4}$ events for each sample were acquired. At least 3 experiment for each sample were performed.

Mixed lymphocyte and tumor cell cultures (MLTC). Peripheral blood mononuclear cells (PBMCs) were obtained at the time of diagnosis from whole blood of autologous RCC85 patient, after obtaining informed consent, under an institutional review board-approved protocol, and were isolated by Ficoll-Hypaque density gradient centrifugation (Sigma Chemical Co., St.Louis, MO, USA), washed twice in phosphate-buffered saline and used in mixed lymphocyte/tumor cell cultures as described below. The RCC $85 \# 21$ line was prior incubated with IFN- $\gamma$ $(100 \mathrm{IU} / \mathrm{ml})$ for $48 \mathrm{~h}$. Autologous PBMCs were co-cultured in 24-well plates (Costar, Corning, CA, USA) at $10^{6}$ cells/well with irradiated RCC stimulator cells $\left(10^{5}\right.$ cells/well) in AIM-V
Table II. Features of the primary tumor and RCC $85 \# 21$ derived cell clone.

\begin{tabular}{ll} 
Clinical features & \\
\hline Age/gender & $62 / \mathrm{M}$ \\
Size & $10 \mathrm{~cm}$ \\
Histological grade & 1 \\
Cytology & Clear cell \\
Invasion of artery/vein & No \\
Lymph node metastasis & T3aN0M0 \\
Cell line (RCC85\#21) & \\
Start date of culture & $17 / 07 / 01$ \\
Number of passages & 50 \\
Doubling time & $72 \mathrm{~h}$ \\
Cell contour & Flat \\
Nuclei & Multinucleated \\
Cell appearance & Polygonal
\end{tabular}

Clinical and pathological features of the primary tumor and in vitro characteristics of the RCC85\#21 derived cell clone.

medium (Life Technologies, Invitrogen, Italy) supplemented with $10 \%$ heat-inactivated pooled human serum [Sigma (medium Mb)]. Recombinant human IL-2 was added on day 3 (250 IU/ml; Proleukin, Chiron, and Emeryville, CA, USA). Responder lymphocytes were restimulated weekly with $10^{5}$ irradiated tumor cells in IL-2-containing $\mathrm{Mb}$ medium for a further 2 weeks. On day 21 (T21) CD8 ${ }^{+}$lymphocytes were selected by immunomagnetic $\mathrm{CD} 8^{+}$microbeads (Miltenyi Biotec, Milan, Italy) and positively-isolated $\mathrm{T}$ cells were cultured for an additional 2 weeks. On day 35 of culture, $\mathrm{CD} 8^{+}$ $\mathrm{T}$ cell responders were used as effector cells in functional and molecular analyses.

Enzyme-linked immunosorbent spot assays (ELISPOT). $\mathrm{CD} 8^{+}$responder $\mathrm{T}$ cells were assessed for specific cytokine production using hIFN- $\gamma$ enzyme-linked immunosorbent spot (ELISPOT) assays (Mabtech, Mariemont, OH, USA), as previously described (22). Determinations were performed in triplicate and spots were counted using an ELISPOT plate reader (Zeiss-Kontron, Jena, Germany). HLA-restriction of $\mathrm{T}$ cell recognition was determined by the addition of blocking antibodies (W6/32, an anti-HLA class I kindly donated by W.J. Storkus) at final concentrations of $100 \mathrm{mg} / \mathrm{ml}$ to replicate ELISPOT wells. At least 3 experiments for each sample were performed.

Cytotoxicity test. Responder $\mathrm{CD}^{+} \mathrm{T}$ cells stimulated by MLTC assay were evaluated at day $30+6$ for their ability to kill target cells, including the patient-derived RCC cell line, EBV-LCL, and K562 cells (erythroid cell line) in standard 4-h ${ }^{51} \mathrm{Cr}$-release assays (23).

Statistical analysis. The results of quantitative variables are expressed as mean \pm SD. All experiments were repeated 

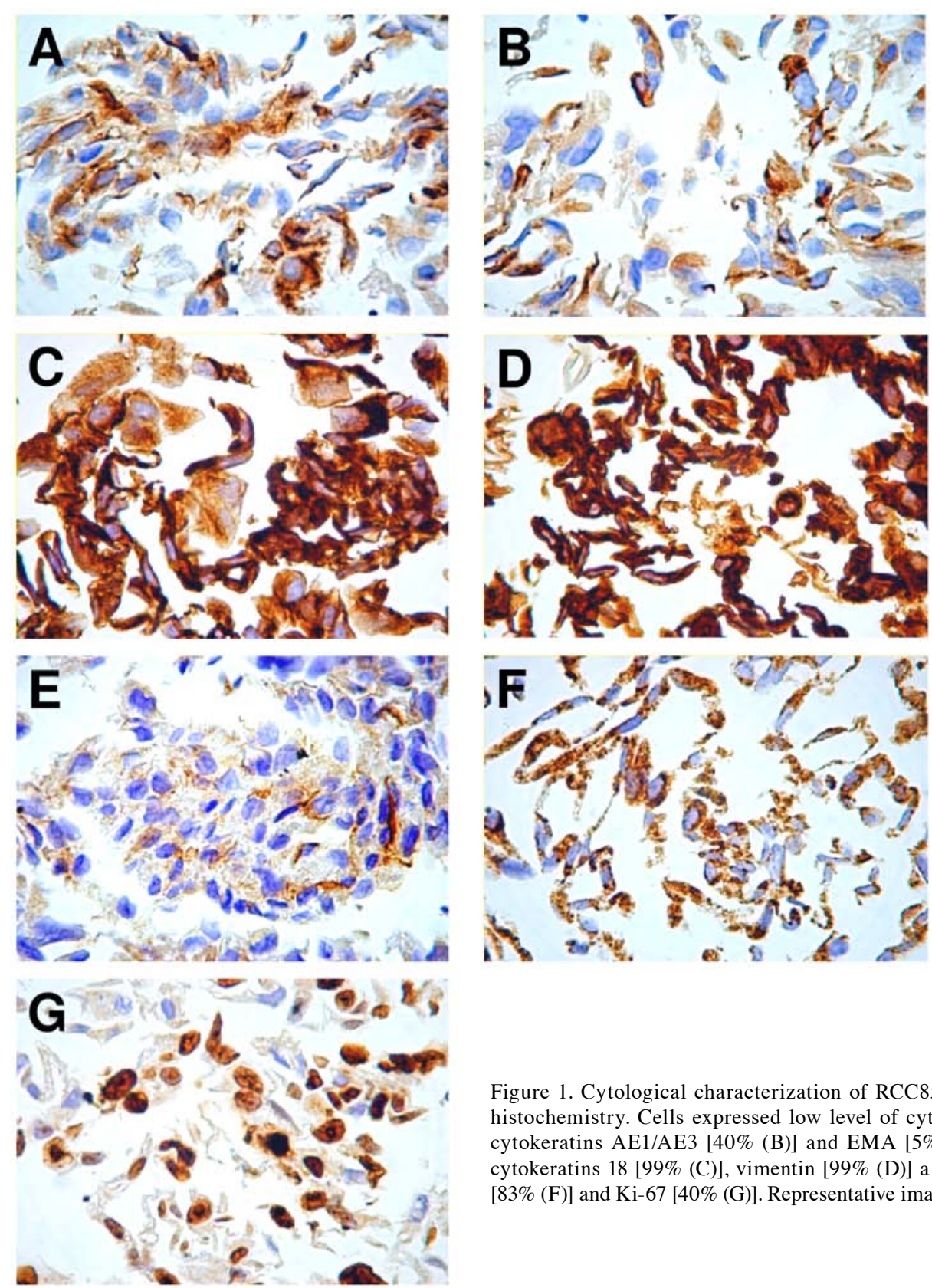

Figure 1. Cytological characterization of RCC $85 \# 21$ clone by immunohistochemistry. Cells expressed low level of cytokeratins 19 [25\% (A)], cytokeratins AE1/AE3 [40\% (B)] and EMA [5\% (E)] and high level of cytokeratins 18 [99\% (C)], vimentin [99\% (D)] a marker of mitochondria [83\% (F)] and Ki-67 [40\% (G)]. Representative images are shown.

more than three times and similar results were observed. Comparisons between data groups were performed using the nonparametric Mann-Whitney rank sum U test. Values of $\mathrm{p} \leq 0.05$ were considered statistically significant.

\section{Results}

RCC85\#21 cell line isolation and cloning. The RCC85 tumor cell line was cultured in complete medium added with $20 \%$ FBS and cloned by the scalar dilution method to obtain a single cell per culture plate well. The RCC85\#21 clone showed a homogeneous cell shape, being polygonal and multinucleated with nuclei positioned at the center of the cytoplasm, and tended to form cellular clusters. The proliferative rate remained constant with trypsinization to $90 \%$ cells confluence every $72 \mathrm{~h}$. The clinical and pathological characteristics of the RCC 85 patients are listed in Table II. RCC 85 cells

were cloned by the limiting dilution technique at step P39. Through this procedure, several clones were isolated from a single cell placed in culture in a 96-well plate, but only one, the RCC85\#21 clone named Elthem, showed morphological and functional characteristics that could define an immunogenic renal tumor cell line.

Phenotypic characterization of the RCC85\#21 cell line. The tumor phenotype characterization and confirmation of the epithelial origin of RCC $85 \# 21$ cells were performed by immunocytochemistry and flow cytometry analysis. Trypsin was not used to avoid altering the membrane antigens and subsequent specific binding with the antibody used for immunostaining. Cells were inbedded in paraffin. Cytokeratins 18, a marker of mitochondria, vimentin and $\mathrm{Ki}-67$, were strongly positive (40-90\%) and cytokeratins AE1/AE3, cytokeratins 19 and EMA were weakly positive (5-30\%) (Fig. 1). Flow cytometry 


\section{RCC85\#21 Basal}

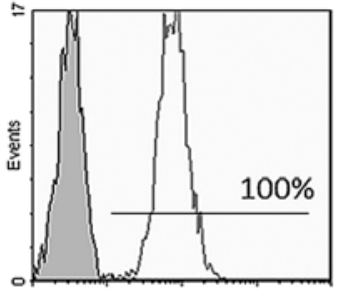

HLA-I FITC

\section{RCC85\#21 + IFN- $\gamma$}

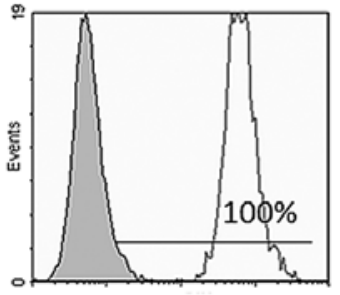

HLA-I FITC

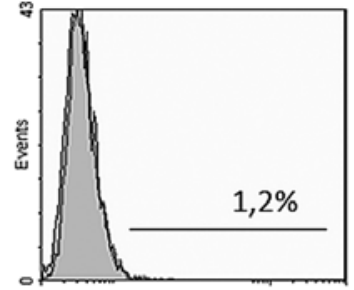

HLA-II PE

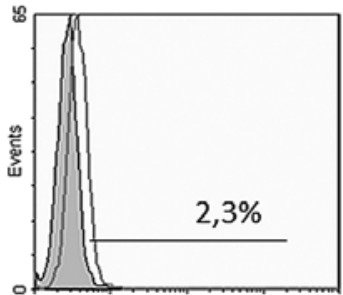

HLA-I I PE

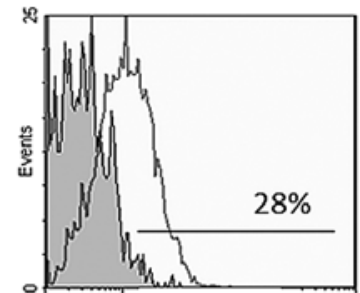

CD40-FITC

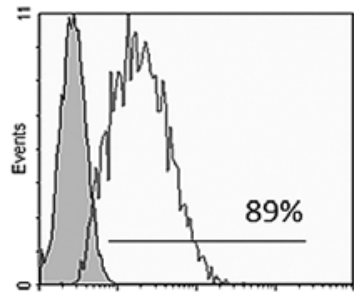

CD40-FITC

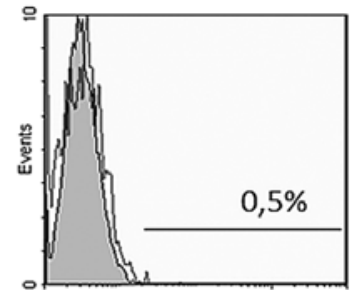

CD80-PE

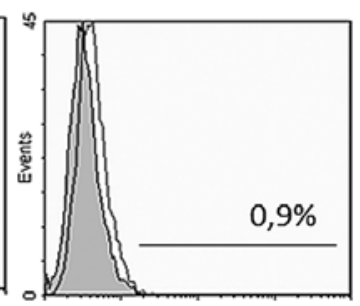

CD80-PE

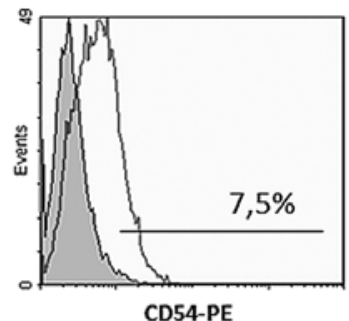

CD54-PE

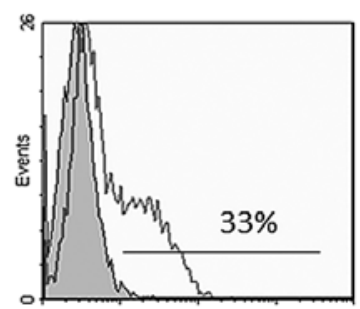

CD54-PE

Figure 2. Phenotypic characterization of the RCC $85 \# 21$ clone by flow cytometry. The percentage indicates the expression of the analyzed costimulatory markers on RCC $85 \# 21$ cells. The data presented are representative of 3 independent experiments performed using RCC85\#21 clone.

A

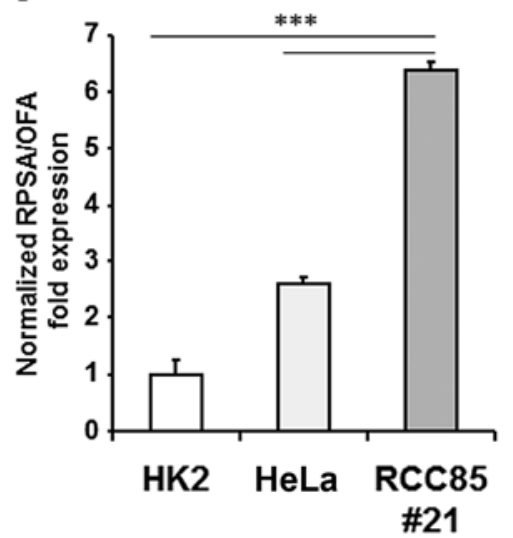

C

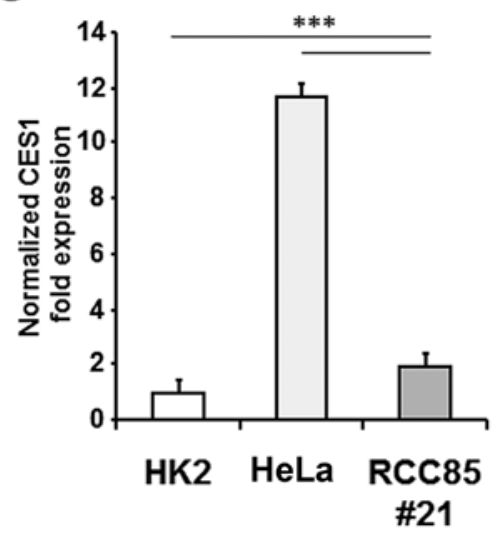

B

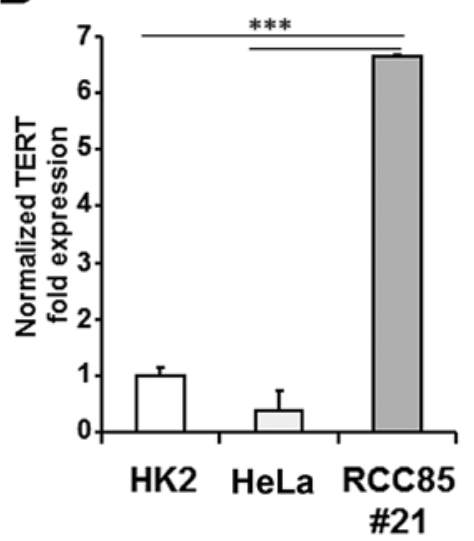

D

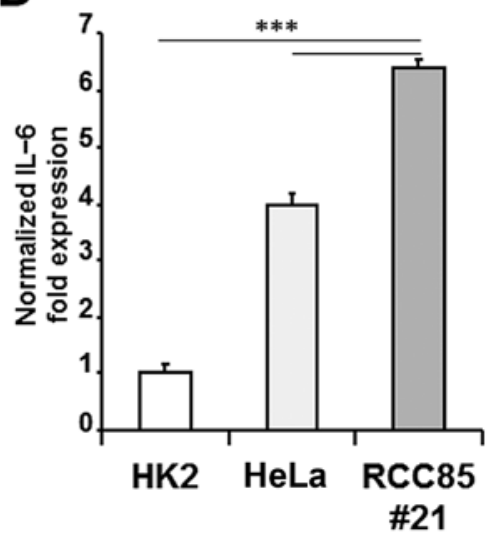

Figure 3. Real-time PCR of tumor markers (OFA, CES1, TERT) and interleukin-6 in the RCC85\#21 clone. The expression levels of RPSA/OFA (A), TERT (B), CES1 (C) and IL-6 (D) genes were upregulated in the RCC85\#21 cell line as compared to HK2 cells ${ }^{* * * *}$ p $\left.<0.001\right)$, while the expression levels of RPSA/OFA, TERT and IL-6 genes were upregulated in the RCC85\#21 cell line compared to HeLa cells $\left(^{* * *}\right.$ p $\left.<0.001\right)$ and CES1 gene expression was decreased as compared to HeLa cells $\left(^{* * * *} \mathrm{p}<0.001\right)$. The data are presented as relative quantity $(\mathrm{RQ})$ of target genes, normalized with respect to ACTB and the calibrator sample $(\mathrm{HK} 2)$. Data are representative of three independent experiments.

analysis revealed that RCC85\#21 cells expressed a high percentage of HLA-class-I (100\%) and a lower rate of CD40
(28\%) and CD54 (7.5\%) molecules when compared with cells stimulated with IFN- $\gamma$ (Fig. 2). By contrast, HLA-class-II and 


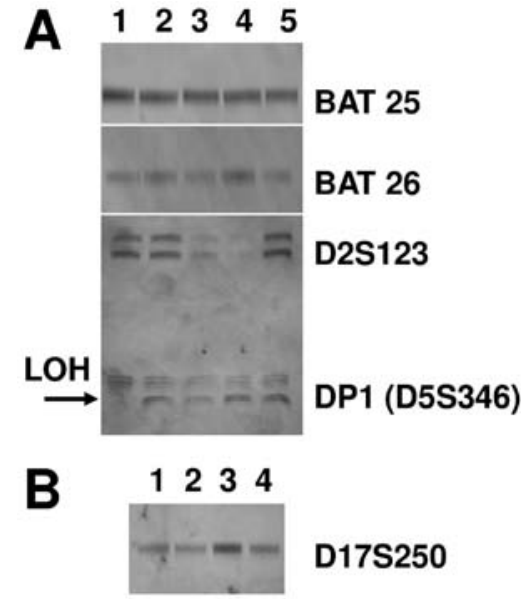

Figure 4. Microsatellite instability (MSI) and loss of heterozygosity (LOH) of the RCC $85 \# 21$ clone. Data are representative of three independent experiments. (A) No difference in MSI in the RCC85\#21 cell line was found as compared to control at the locus BAT25, BAT26 and D2S123 (lane 1, RCC85\#21; lane 2, PBMC, peripheral blood mononuclear cells; lane 3, RCC1; lane 4, RCC3; lane 5, RCC2), but LOH was observed at the locus DP1 or D5S346 in the RCC85\#21 clone but not in the renal cancer cell lines from which it was generated (RCC1/RCC2/RCC3). (B) No difference in MSI in the RCC85\#21 cell line was found as compared to control at the locus D17S250 (lane 1, RCC2; lane 2, RCC3; lane 3, RCC85\#21; lane 4, PBMC, peripheral blood mononuclear cells).

costimulatory CD80 molecules were not detectable under basal conditions nor after stimulation with IFN- $\gamma$.
Real-time PCR and genetic instability. The RCC85\#21 clone was characterized by real-time PCR to evaluate the expression of tumor and inflammatory biomarkers, such as RPSA alias OFA/iLRP (RQ $=6.3 \pm 0.15)$, TERT $(\mathrm{RQ}=2.0 \pm 0.28$ ), CES1 (RQ = 6.6 \pm 0.05$)$ and IL-6 $(\mathrm{RQ}=6.3 \pm 0.20)$. As shown in Fig. 3, the expression levels of RPSA/OFA, TERT and IL-6 genes were significantly upregulated in the RCC $85 \# 21$ cell line as compared to HK2 cells and HeLa cells $(\mathrm{p}<0.001)$. The expression level of CES1 was significantly upregulated in the RCC85\#21 cell line as compared to HK2 ( $<0.001)$, while CES1 gene expression resulted decreased as compared to HeLa tumor cells $(p<0.001)$. Genome instability was studied by evaluating microsatellite instability (MSI) and loss of heterozygosity ( $\mathrm{LOH}$ ) with a standard panel of 5 markers, already used to characterize other tumors (24). No difference in MSI in the RCC85\#21 cell line was found as compared to control (Fig. 3). LOH was observed at the locus DP1 or D5S346 in the RCC $85 \# 21$ clone but not in the renal cancer cell lines from which it was generated (Fig. 4) (26).

$2 D E$ and $M S$ analysis. Image analysis of silver stained RCC $85 \# 21$ gels showed $700 \pm 26$ spots. An average of 250 spots was selected from two different Coomassie Blue-stained preparative gels representing the total proteome displayed; among them 119 spots were identified, corresponding to 99 different proteins. The proteome map was drawn by identifying protein spots present in at least three out of four analytical gels. Table III lists all the identified proteins corresponding to the protein spots presented on Fig. 5. Their

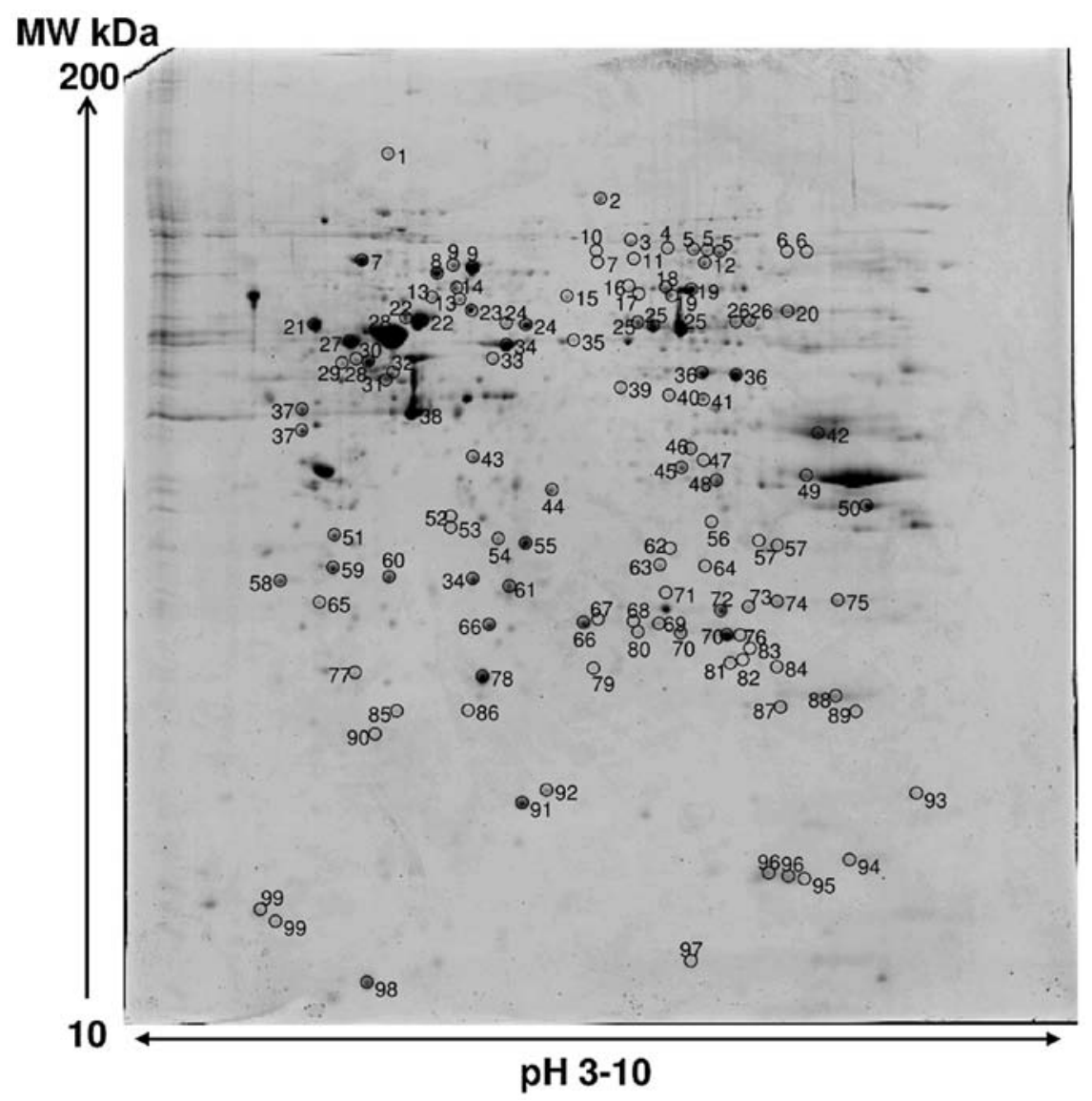

Figure 5. Representative 2-DE map of proteins extracted from the RCC85\#21 clone. The image analysis of three different gels showed $700 \pm 26$ spots. 
Table III. Protein spots identified by MALDI-TOF analysis.

\begin{tabular}{|c|c|c|c|c|c|c|c|}
\hline Spot ID & $\begin{array}{c}\text { Accession } \\
\text { no. }\end{array}$ & Protein name & $\begin{array}{l}\text { Mascot } \\
\text { score }\end{array}$ & $\begin{array}{c}\text { Sequence } \\
\text { coverage }(\%)\end{array}$ & $\begin{array}{l}\text { N. matched } \\
\text { peptides }\end{array}$ & PI & $\mathrm{PM}(\mathrm{Da})$ \\
\hline 1 & Q9Y4L1 & $\begin{array}{l}\text { Oxygen-regulated protein } \\
\text { precursor }\end{array}$ & 126 & 20 & 22 & 5.16 & 111,266 \\
\hline 2 & P18206 & Vinculin & $88^{\mathrm{a}}$ & 26 & 20 & 5.5 & 124,292 \\
\hline 3 & Q8WUM4 & $\begin{array}{l}\text { Programmed cell death } \\
\text { 6-interacting protein }\end{array}$ & 71 & 21 & 21 & 6.13 & 95,963 \\
\hline 4 & Q12931 & Heat shock protein 75 & & 18 & 17 & 6.09 & 73,971 \\
\hline 5 & P02545 & Lamin-A/C & 281 & 45 & 42 & 6.57 & 74,095 \\
\hline 6 & Q92804 & $\begin{array}{l}\text { TATA-binding protein- } \\
\text { associated factor } 2 \mathrm{~N}\end{array}$ & $56^{\mathrm{a}}$ & 20 & 13 & 8.04 & 61,793 \\
\hline 7 & P11021 & $\begin{array}{l}\text { Glucose-regulated protein } \\
\text { precursor }\end{array}$ & 231 & 37 & 29 & 5.07 & 72,402 \\
\hline 8 & P11142 & $\begin{array}{l}\text { Heat shock cognate } 71 \mathrm{kDa} \\
\text { protein }\end{array}$ & 293 & 43 & 36 & 5.37 & 71,082 \\
\hline 9 & P38646 & Stress- 70 protein & 330 & 47 & 43 & 5.87 & 73,635 \\
\hline 10 & Q59GB4 & $\begin{array}{l}\text { Dihydropyrimidinase-like } 2 \\
\text { variant }\end{array}$ & 106 & 27 & 15 & 5.85 & 68,142 \\
\hline 11 & P15311 & Ezrin & $73^{\mathrm{a}}$ & 20 & 16 & 5.94 & 69,199 \\
\hline 12 & P49915 & $\begin{array}{l}\text { GMP synthase [glutamine- } \\
\text { hydrolyzing] }\end{array}$ & $179^{\mathrm{a}}$ & 42 & 32 & 6.42 & 76,667 \\
\hline 13 & P61978 & $\begin{array}{l}\text { Heterogeneous nuclear } \\
\text { ribonucleusprotein } \mathrm{K}\end{array}$ & 144 & 33 & 24 & 5.39 & 51,230 \\
\hline 14 & Q03252 & Lamin-2 & $186^{\mathrm{a}}$ & 53 & 33 & 5.29 & 67,647 \\
\hline 15 & P17987 & $\begin{array}{l}\text { T-complex protein } 1 \\
\text { subunit } \alpha\end{array}$ & $140^{\mathrm{a}}$ & 33 & 24 & 5.8 & 60,306 \\
\hline 16 & P49368 & T-complex protein 1 subunit $\gamma$ & $174^{\mathrm{a}}$ & 37 & 27 & 6.1 & 60,495 \\
\hline 17 & P36871 & Phosphoglucomutase-1 & 91 & 36 & 19 & 6.32 & 61,279 \\
\hline 18 & P31948 & $\begin{array}{l}\text { Stress-induced- } \\
\text { phosphoprotein } 1\end{array}$ & 104 & 36 & 25 & 6.40 & 62,599 \\
\hline 19 & P31939 & $\begin{array}{l}\text { Bifunctional purine } \\
\text { biosynthesis protein }\end{array}$ & 107 & 22 & 14 & 6.39 & 64,425 \\
\hline 20 & P14618 & $\begin{array}{l}\text { Pyruvate kinase isozyme } \\
\text { M1/M2 }\end{array}$ & 110 & 27 & 13 & 7.96 & 58,470 \\
\hline 21 & P07237 & $\begin{array}{l}\text { Protein disulfide-isomerase } \\
\text { precursor }\end{array}$ & 300 & 55 & 38 & 4.76 & 57,480 \\
\hline 22 & P10809 & $\begin{array}{l}\text { Heat shock protein, } \\
\text { mitochondrial precursor }\end{array}$ & 131 & 34 & 21 & 5.7 & 61,187 \\
\hline 23 & P48643 & $\begin{array}{l}\text { T-complex protein } 1 \\
\text { subunit } \varepsilon\end{array}$ & $176^{\mathrm{a}}$ & 37 & 23 & 5.45 & 59,633 \\
\hline 24 & P30101 & $\begin{array}{l}\text { Protein disulfide-isomerase } \\
\text { A3 precursor }\end{array}$ & 166 & 38 & 24 & 5.98 & 57,146 \\
\hline 25 & P00352 & Retinal dehydrogenase 1 & 206 & 37 & 22 & 6.29 & 54,696 \\
\hline 26 & O60701 & $\begin{array}{l}\text { UDP-glucose 6- } \\
\text { dehydrogenase }\end{array}$ & 189 & 44 & 22 & 6.73 & 55,674 \\
\hline
\end{tabular}


Table III. Continued.

\begin{tabular}{|c|c|c|c|c|c|c|c|}
\hline Spot ID & $\begin{array}{l}\text { Accession } \\
\text { no. }\end{array}$ & Protein name & $\begin{array}{l}\text { Mascot } \\
\text { score }\end{array}$ & $\begin{array}{c}\text { Sequence } \\
\text { coverage }(\%)\end{array}$ & $\begin{array}{l}\text { N. matched } \\
\text { peptides }\end{array}$ & PI & $\mathrm{PM}(\mathrm{Da})$ \\
\hline 27 & P07437 & Tubulin $\beta$ chain & 57 & 15 & 5 & 4.78 & 50,095 \\
\hline 28 & P08670 & Vimentin & 369 & 82 & 43 & 5.06 & 53,676 \\
\hline 29 & Q969G3 & $\begin{array}{l}\text { SWI/SNF-related matrix- } \\
\text { associated actin-dependent } \\
\text { regulator of chromatin } \\
\text { subfamily E member } 1\end{array}$ & 93 & 31 & 14 & 4.85 & 46,621 \\
\hline 30 & P06576 & $\begin{array}{l}\text { ATP synthase subunit } \beta \text {, } \\
\text { mitochondrial precursor }\end{array}$ & 133 & 25 & 9 & 5.26 & 56,525 \\
\hline 31 & P43686 & $\begin{array}{l}26 \mathrm{~S} \text { protease regulatory } \\
\text { subunit } 6 \mathrm{~B}\end{array}$ & 114 & 31 & 14 & 5.09 & 47,337 \\
\hline 32 & Q15084 & $\begin{array}{l}\text { Protein disulfide-isomerase } \\
\text { A6 precursor }\end{array}$ & 64 & 19 & 7 & 4.95 & 48,091 \\
\hline 33 & Q9Y230 & RuvB-like 2 & 99 & 43 & 19 & 5.49 & 50,994 \\
\hline 34 & Q13561 & Dynactin subunit 2 & $80^{\mathrm{a}}$ & 42 & 14 & 5.1 & 44,318 \\
\hline 35 & P31943 & $\begin{array}{l}\text { Heterogeneous nuclear } \\
\text { ribonucleusprotein } \mathrm{H}\end{array}$ & 116 & 31 & 14 & 5.89 & 49,484 \\
\hline 36 & P06733 & $\alpha$-enolase & 233 & 60 & 29 & 7.01 & 47,481 \\
\hline 37 & Q15293 & Reticulocalbin-1 precursor & 91 & 29 & 7 & 4.86 & 38,866 \\
\hline 38 & P63261 & Actin, cytoplasmic 2 & $79^{\mathrm{a}}$ & 38 & 8 & 5.31 & 42,108 \\
\hline 39 & O60664 & $\begin{array}{l}\text { Mannose-6-phosphate } \\
\text { receptor-binding protein } 1\end{array}$ & 105 & 45 & 12 & 5.3 & 47,189 \\
\hline 40 & P61163 & $\alpha$-centractin & 94 & 30 & 9 & 8 & 42,701 \\
\hline 41 & P49411 & $\begin{array}{l}\text { Elongation factor Tu, } \\
\text { mitochondrial precursor }\end{array}$ & $121^{\mathrm{a}}$ & 45 & 16 & 7.26 & 49,852 \\
\hline 42 & P04075 & $\begin{array}{l}\text { Fructose-bisphosphate } \\
\text { aldolase A }\end{array}$ & 66 & 38 & 11 & 8.3 & 39,851 \\
\hline 43 & Q13347 & $\begin{array}{l}\text { Eukaryotic translation } \\
\text { initiation factor } 3 \text { subunit } 2\end{array}$ & 117 & 45 & 11 & 5.38 & 36,878 \\
\hline 44 & P52907 & $\begin{array}{l}\text { F-actin capping protein } \\
\text { subunit } \alpha-1\end{array}$ & 81 & 50 & 9 & 5.45 & 33,073 \\
\hline 45 & Q99439 & Calponin-2 & $64^{\mathrm{a}}$ & 43 & 12 & 6.95 & 34,074 \\
\hline 46 & Q96PM5 & $\begin{array}{l}\text { RING finger and CHY zinc } \\
\text { finger domain-containing } \\
\text { protein } 1\end{array}$ & $64^{\mathrm{a}}$ & 28 & 6 & 6.26 & 31,743 \\
\hline 47 & P31942 & $\begin{array}{l}\text { Heterogeneous nuclear } \\
\text { ribonucleus protein } \mathrm{H} 3\end{array}$ & $61^{\mathrm{a}}$ & 47 & 12 & 6.37 & 36,960 \\
\hline 48 & Q5T0U0 & $\begin{array}{l}\text { Coiled-coil domain- } \\
\text { containing protein } 122\end{array}$ & $71^{\mathrm{a}}$ & 44 & 12 & 6.54 & 32,415 \\
\hline 49 & Q8TBZ5 & Zinc finger protein 502 & $65^{\mathrm{a}}$ & 15 & 9 & 9.02 & 65,046 \\
\hline 50 & P22626 & $\begin{array}{l}\text { Heterogeneous nuclear } \\
\text { ribonucleoproteins A2/B1 }\end{array}$ & 64 & 35 & 12 & 8.97 & 37,464 \\
\hline 51 & P09493 & Tropomyosin $\alpha-1$ chain & 91 & 26 & 10 & 4.69 & 32,746 \\
\hline 52 & Q15181 & Inorganic pyrophosphatase & 103 & 50 & 9 & 5.54 & 33,095 \\
\hline
\end{tabular}


Table III. Continued.

\begin{tabular}{|c|c|c|c|c|c|c|c|}
\hline Spot ID & $\begin{array}{l}\text { Accession } \\
\text { no. }\end{array}$ & Protein name & $\begin{array}{l}\text { Mascot } \\
\text { score }\end{array}$ & $\begin{array}{c}\text { Sequence } \\
\text { coverage }(\%)\end{array}$ & $\begin{array}{l}\text { N. matched } \\
\text { peptides }\end{array}$ & PI & PM (Da) \\
\hline 53 & Q9HC38 & $\begin{array}{l}\text { Glyoxalase domain- } \\
\text { containing protein } 4\end{array}$ & $65^{\mathrm{a}}$ & 19 & 9 & 5.4 & 35,170 \\
\hline 54 & P47756 & $\begin{array}{l}\text { F-actin capping protein } \\
\text { subunit } \beta\end{array}$ & 72 & 32 & 10 & 5.36 & 31,331 \\
\hline 55 & P09525 & Annexin A4 & 227 & 61 & 28 & 5.84 & 35,860 \\
\hline 56 & P10768 & $\begin{array}{l}\text { S-formylglutathione } \\
\text { hydrolase }\end{array}$ & $118^{\mathrm{a}}$ & 37 & 11 & 6.54 & 31,956 \\
\hline 57 & P63244 & $\begin{array}{l}\text { Guanine nucleotide- } \\
\text { binding protein } \\
\text { subunit } \beta \text {-2-like } 1\end{array}$ & 202 & 58 & 17 & 7.6 & 35,055 \\
\hline 58 & P24534 & Elongation factor $1-\beta$ & 116 & 44 & 12 & 4.5 & 24,748 \\
\hline 59 & P06753 & Tropomyosin $\alpha-3$ chain & 230 & 58 & 23 & 4.75 & 29,015 \\
\hline 60 & O00299 & $\begin{array}{l}\text { Chloride intracellular } \\
\text { channel protein } 1\end{array}$ & 207 & 64 & 14 & 5.09 & 26,906 \\
\hline 61 & P07339 & Cathepsin D chain B & $100^{\mathrm{a}}$ & 28 & 9 & 5.31 & 26,229 \\
\hline 62 & Q13011 & $\begin{array}{l}\operatorname{Delta}(3,5)-\operatorname{Delta}(2,4)- \\
\text { dienoyl-CoA isomerase }\end{array}$ & 89 & 29 & 8 & 8.16 & 35,793 \\
\hline 63 & $\mathrm{P} 25786$ & Proteasome subunit $\alpha$ type- 1 & 173 & 46 & 16 & 6.15 & 29,537 \\
\hline 64 & Q8WUF0 & $\omega$-amidase NIT2 & $131^{\mathrm{a}}$ & 40 & 9 & 6.82 & 30,561 \\
\hline 65 & Q6P3U9 & $14-3-3$ protein $\zeta / \delta$ & 115 & 36 & 15 & 4.73 & 27,899 \\
\hline 66 & P04792 & Heat shock protein $\beta$-1 & 133 & 51 & 11 & 5.98 & 22,826 \\
\hline 67 & Q9NVS9 & $\begin{array}{l}\text { Pyridoxine-5'-phosphate } \\
\text { oxidase }\end{array}$ & 95 & 43 & 9 & 6.62 & 29,969 \\
\hline 68 & P30040 & $\begin{array}{l}\text { Endoplasmic reticulum } \\
\text { resident protein } 29\end{array}$ & 65 & 27 & 8 & 6.77 & 28,975 \\
\hline 69 & P30041 & Peroxiredoxin-6 & 114 & 39 & 11 & 6 & 25,133 \\
\hline 70 & P60174 & Triosephosphate isomerase & 183 & 63 & 15 & 6.45 & 26,938 \\
\hline 71 & P18669 & Phosphoglycerate mutase 1 & 130 & 60 & 14 & 6.67 & 28,900 \\
\hline 72 & P00918 & Carbonic anhydrase 2 & 94 & 50 & 9 & 6.87 & 29,228 \\
\hline 73 & Q15056 & $\begin{array}{l}\text { Eukaryotic translation } \\
\text { initiation factor } 4 \mathrm{H}\end{array}$ & 89 & 35 & 8 & 6.67 & 27,368 \\
\hline 74 & O15305 & Phosphomannomutase 2 & $70^{\mathrm{a}}$ & 25 & 10 & 6.35 & 28,406 \\
\hline 75 & P17931 & Galectin-3 & $149^{\mathrm{a}}$ & 40 & 13 & 8.58 & 26,172 \\
\hline 76 & Q9Y5U2 & Protein TSSC4 & $64^{\mathrm{a}}$ & 24 & 9 & 5.02 & 34,436 \\
\hline 77 & Q04760 & Lactoylglutathione lyase & 76 & 60 & 9 & 5.12 & 20,992 \\
\hline 78 & P09211 & Glutathione S-transferase P & 95 & 48 & 8 & 5.43 & 23,569 \\
\hline 79 & P30048 & $\begin{array}{l}\text { Thioredoxin-dependent } \\
\text { peroxide reductase }\end{array}$ & 72 & 30 & 6 & 7.67 & 28,017 \\
\hline 80 & Q9Y224 & UPF0568 protein C14orf166 & 72 & 40 & 8 & 6.19 & 28,051 \\
\hline 81 & $\mathrm{P} 25787$ & Proteasome subunit $\alpha$ type- 2 & 116 & 44 & 11 & 6.92 & 25,882 \\
\hline 82 & Q92507 & $\begin{array}{l}\text { ES1 protein homolog, } \\
\text { mitochondrial precursor }\end{array}$ & 111 & 65 & 12 & 8.5 & 28,153 \\
\hline
\end{tabular}


Table III. Continued.

\begin{tabular}{|c|c|c|c|c|c|c|c|}
\hline Spot ID & $\begin{array}{l}\text { Accession } \\
\text { no. }\end{array}$ & Protein name & $\begin{array}{l}\text { Mascot } \\
\text { score }\end{array}$ & $\begin{array}{c}\text { Sequence } \\
\text { coverage }(\%)\end{array}$ & $\begin{array}{l}\text { N. matched } \\
\text { peptides }\end{array}$ & PI & $\mathrm{PM}(\mathrm{Da})$ \\
\hline 83 & Q99714 & $\begin{array}{l}\text { Hydroxyacyl-CoA } \\
\text { dehydrogenase type-2 }\end{array}$ & 60 & 22 & 6 & 7.66 & 27,134 \\
\hline 84 & P30043 & $\begin{array}{l}\text { Flavin reductase (NADPH- } \\
\text { dependent diaphorase) }\end{array}$ & 127 & 58 & 12 & 7.13 & 22,105 \\
\hline 85 & O75947 & $\begin{array}{l}\text { ATP synthase D chain, } \\
\text { mitochondrial }\end{array}$ & $77^{\mathrm{a}}$ & 65 & 11 & 5.21 & 18,537 \\
\hline 86 & P07741 & $\begin{array}{l}\text { Adenine } \\
\text { phosphoribosyltransferase }\end{array}$ & $68^{\mathrm{a}}$ & 32 & 6 & 5.78 & 19,595 \\
\hline 87 & P30086 & $\begin{array}{l}\text { Phosphatidylethanolamine- } \\
\text { binding protein } 1\end{array}$ & $100^{\mathrm{a}}$ & 55 & 7 & 7.01 & 21,044 \\
\hline 88 & Q06830 & Peroxiredoxin-1 & 84 & 24 & 5 & 8.27 & 22,096 \\
\hline 89 & P37802 & Transgelin-2 & 76 & 35 & 6 & 8.41 & 22,377 \\
\hline 90 & P30626 & Sorcin & 72 & 49 & 11 & 5.32 & 21,947 \\
\hline 91 & P00441 & $\begin{array}{l}\text { Superoxide dismutase } \\
{[\mathrm{Cu}-\mathrm{Zn}]}\end{array}$ & 57 & 38 & 5 & 5.7 & 16,154 \\
\hline 92 & Q86XQ2 & $\begin{array}{l}\text { Nucleoside diphosphate } \\
\text { kinase A }\end{array}$ & 131 & 49 & 9 & 5.42 & 19,641 \\
\hline 93 & P23284 & $\begin{array}{l}\text { Peptidyl-prolyl cis-trans } \\
\text { isomerase B }\end{array}$ & 97 & 42 & 12 & 9.33 & 22,785 \\
\hline 94 & P23528 & Cofilin-1 & 117 & 71 & 11 & 8.22 & 18,719 \\
\hline 95 & $\mathrm{P} 14550$ & $\begin{array}{l}\text { Alcohol dehydrogenase } \\
{\left[\mathrm{NADP}^{+}\right] \text {fragment }}\end{array}$ & 118 & 42 & 16 & 6.32 & 36,892 \\
\hline 96 & P62937 & $\begin{array}{l}\text { Peptidyl-prolyl cis-trans } \\
\text { isomerase A }\end{array}$ & 90 & 53 & 12 & 7.68 & 18,229 \\
\hline 97 & P49773 & $\begin{array}{l}\text { Histidine triad nucleotide- } \\
\text { binding protein } 1\end{array}$ & 62 & 75 & 8 & 6.43 & 13,907 \\
\hline 98 & P09382 & Galectin-1 & 109 & 47 & 7 & 5.34 & 15,048 \\
\hline 99 & P60660 & Myosin light polypeptide 6 & 68 & 47 & 10 & 4.56 & 17,090 \\
\hline
\end{tabular}

The first column shows the number of spots corresponding to Fig. 4, the second the accession number of each protein, the third the name of the protein, the fourth the mascot score, in the fifth and the sixth the percentage of coverage and the number of peptides matched are shown, while the last two columns show the isoelectric point (pI) and molecular weight expressed in dalton. ${ }^{\mathrm{a}} 100 \mathrm{pm}$.

function and localization was derived from the databases of NCBI and SWISS-PROT (http://www.ncbi.nlm.nih.gov, http://us.expasy.org/sprot/). Cytoskeleton proteins (structural proteins), chaperones, proteins involved in energy, carbohydrates, amino acids and the basal metabolism were identified. Different enzymes were identified as isomerases, oxidoreductases and proteases, as well as the channel protein family, the proteasome complex, actin and calcium binding proteins and proteins involved in apoptotic and proliferative processes. Most of the identified proteins are cytoplasmic proteins (structural proteins). Several lysosomal enzymes were identified, as well as membrane proteins (protein channels and receptors).
The cellular function of each identified protein was searched for in several proteic and bibliographic databases (SWISSPROT and PubMed) to assess the impact on the biology of the tumor, confirming their role in several pathophysiological mechanisms. Some of these identified proteins were components of the cytoskeleton such as Lamin-A/C, vimentin and the tropomyosin $\alpha-3$ chain. Vimentin has already been shown to be abundant in kidney cancer cell lines (27). Cofilin-1, the F-actin capping protein $\beta$-and $\alpha$-1 subunit, Actin cytoplasmic 2 and Stress-70 protein were essential in the reorganization of actin filaments as a cellular response to various growth factors (28). Enzymes with a different catalytic activity were 

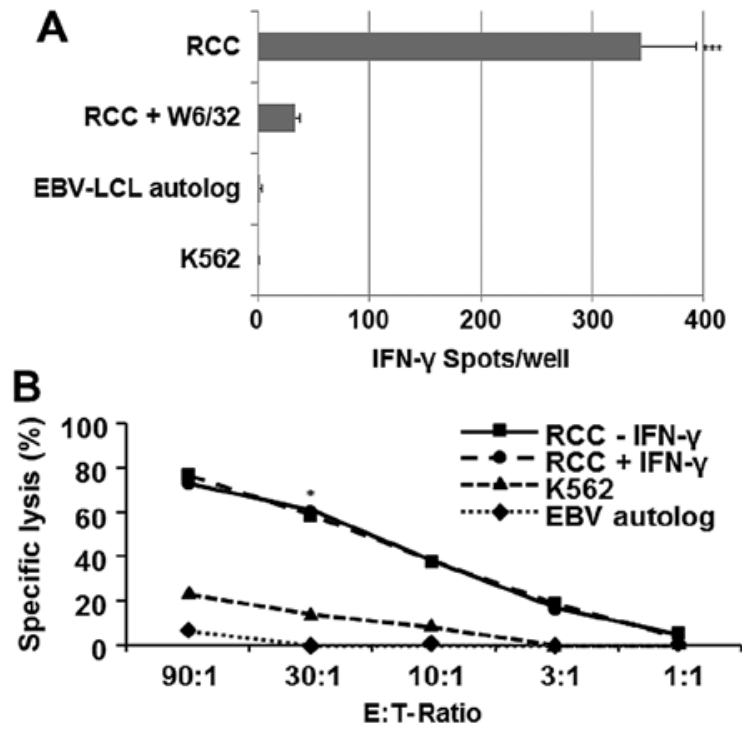

Figure 6. ELISPOT test for IFN- $\gamma$ release (A) and cytotoxic T cell responses using ${ }^{51} \mathrm{Cr}$-release assays (B). (A) Frequencies of responder $\mathrm{CD} 8{ }^{+} \mathrm{T}$ cells reactive against RCC85\#21, EBV-LCL and K562 cell lines after MLTC stimulation (day 35). Results represent the average $( \pm \mathrm{SD}$ ) of triplicate wells and are the mean $( \pm \mathrm{SD})$ of values obtained from three independent experiments (**** $\mathrm{p}<0.001$, RCC85\#21 vs EBV-LCL and K562). (B) CD8 ${ }^{+} \mathrm{T}$ cells stimulated by MLTC assay were evaluated at day 35 for their ability to kill target cells including patient-derived RCC cell lines, EBV-LCL cells and K562 (erythroid cell lines) in standard $4-\mathrm{h}{ }^{51} \mathrm{Cr}$-release assays. ${ }^{51} \mathrm{Cr}$-release assays indicated that MLTC responder $\mathrm{CD} 8^{+} \mathrm{T}$ cells efficiently lysed the RCC85\#21 clone $(60 \%$, $\mathrm{E} / \mathrm{T}$ ratio 30:1), while the erythroid $\mathrm{K} 562$ line, used to assess non-specific cytotoxicity, showed a low percentage of lysis $\left(<20 \%\right.$, E/T ratio $\left.30: 1,{ }^{*} \mathrm{p}<0.03\right)$. Data are representative of three independent experiments.

identified (phosphoglucomutase-1 and $\alpha$-enolase). Isomerases such as protein disulfide-isomerase $\mathrm{A} 3$, and protein disulfideisomerase $\mathrm{A} 6$, as well as calcium binding protein (Annexin A4 and Reticulocalbin-1) were also identified, together with proteins involved in the oxidation-reduction processes such as Peroxiredoxin-1 and 6, Thioredoxin-dependent peroxide reductase, Superoxide dismutase $[\mathrm{Cu}-\mathrm{Zn}]$ and energy metabolism (ATP synthase subunit $\beta$ and carbonic anhydrase 2) (29). Apoptosis has an important role in tumor growth and several proteins involved in the apoptosis pathway, key feature of known tumors such as galectin-1 and 3, programmed cell death 6-interacting protein, were identified. Among the other identified proteins, elongation factor 1- $\beta$, eukaryotic translation initiation factor 3 subunit 2, elongation factor Tu were involved in protein synthesis, and pyruvate kinase M1/M2 isozymes and glutathione S-transferase $\mathrm{P}$ in general metabolism. Finally, protein channels (chloride intracellular channel protein 1) and proteins belonging to the family of chaperones responsible for the correct 'folding' of proteins (protein disulfide-isomerase A3, heat shock cognate 71-kDa protein, glucose-regulated protein, T-complex protein 1 subunit $\gamma$ ) were identified in RCC (30).

In vitro evaluation of the immunogenic property of the RCC85\#21 cell line. The RCC85\#21 clone immunogenicity was evaluated after 35 days of MLTC stimulation, where autologous PBMCs were co-cultured with irradiated RCC85\#21 cells. After three weeks of culture $\mathrm{CD}^{+} \mathrm{T}$ cells were isolated and restimulated for two further weeks, in order to obtain and expand RCC-specific $\mathrm{CD} 8^{+} \mathrm{T}$ cells. The degree of immunogenicity was evaluated by testing the release of IFN- $\gamma$ by responder $\mathrm{CD}^{+} \mathrm{T}$ lymphocytes with the ELISPOT assay (Fig. 6A). $\mathrm{CD}^{+} \mathrm{T}$ cells isolated from PBMC patient significantly displayed an elevated (HLA class I-restricted) reactivity against RCC85\#21, but they failed to react against autologous EBV-LCL cells and the K562 target cell lines $(\mathrm{p}<0.001)$. These $\mathrm{CD}^{+}$cytotoxic lymphocytes (CTL) recognized the RCC $85 \# 21$ cell line in a predominantly class I-restricted manner, based on the ability of the anti-HLA class I mAbs (W6-32) to inhibit responses by $91 \%$. Analysis of cytotoxic $\mathrm{CD}^{+} \mathrm{T}$ cell responses using ${ }^{51} \mathrm{Cr}$-release assays similarly indicated that MLTC responder $\mathrm{CD} 8^{+} \mathrm{T}$ cells efficiently lysed the RCC85\#21 clone $(60 \%, \mathrm{E} / \mathrm{T}$ ratio $30: 1)$, while the erythroid K562 line, used to assess non-specific cytotoxicity, showed a low percentage of lysis $(<20 \%, \mathrm{E} / \mathrm{T}$ ratio $30: 1, \mathrm{p}<0.03)$ (Fig. 6B).

\section{Discussion}

Immunogenicity is the principal aspect to be considered in the isolation and characterization of cancer cells, being this feature not always present in cancer cells cultivated in vitro over the past 30 years. In this report, we describe a new tumor cells clone derived from renal primary lesions of ccRCC, that is capable of eliciting a tumor-specific $\mathrm{T}$ cell response in vitro. We characterized the RCC85\#21 clone derived from a RCC patient with histological grade T3aN0M0. The cell line was called Elthem, patented and properly licensed. This cell line has a potential range of benefits in somatic therapy for the treatment of patients affected by RCC. The RCC $85 \# 21$ cell line, obtained by limiting dilution, is a cell clone that is morphologically similar to the tissue of origin, namely multinucleated and polygonal cells with a characteristic cluster growth. The RCC85\#21 cell line showed a typical tumor cell phenotype given its positivity for the characteristic tumor markers of epithelial origin (cytokeratin CAM 5.2, mitochondrial markers, vimentin, cytokeratin AE1/AE3, cytokeratin 19, EMA and Ki-67). Following tumor cell expansion, antigenic characteristics of RCC cell lines were studied and confirmed. We found that RCC $85 \# 21$ lacks the costimulatory molecules CD80 and CD86, suggesting that $\mathrm{T}$ cell priming against the RCC $85 \# 21$ cell line could be activated in the absence of costimulation. Other groups have previously analysed the capacity to induce CTL responses of B7.1 (CD80) or B7.2 (CD86) in modified tumor cells (31). In melanoma cell lines, B7 expression appeared to be necessary to induce allogenic responses, whereas this was not found in the RCC85\#21 line. In fact, based on its immunogenic potential, the RCC $85 \# 21$ line was selected as a well-characterized human renal cell carcinoma line that is capable of inducing autologous and allogenic $\mathrm{CD}^{+}{ }^{+} \mathrm{CD}^{+}$tumor-associated responses by MLTC.

In addition, the expression levels of some tumor (RPSA/ OFA and TERT) and inflammatory (CES1 and IL-6) biomarkers were evaluated by real-time PCR to confirm the tumorigenic and immunogenic capacity of the RCC85\#21 cell line. The expression levels of RPSA/OFA, TERT and IL-6 genes were significantly upregulated in the RCC $85 \# 21$ cell line as compared to HK2 and HeLa cells, while CES1 gene expression was increased in RCC85\#21 cell line when compared 
with HK2 control cells, but decreased when compared to HeLa tumor cells. These data confirmed the tumorigenicity of the RCC85\#21 cell line. MSI and LOH were also evaluated, no differences being observed in MSI, while LOH was identified at locus DP1 or D5S346 on chromosome 5q. LOH on 5q was previously described in $7 / 42(17 \%)$ sporadic RCC patients (26). The minimum region of deletion on $5 q$ to account for $\mathrm{LOH}$ was mapped to 5q31.1 (interferon regulatory factor-1; IRF-1 locus), suggesting that $\mathrm{LOH}$ on $5 \mathrm{q}$ could play an important role in the pathogenesis of RCC. However, recent data have highlighted the low percentage of tumors showing $\mathrm{LOH}$ on $5 \mathrm{q}$ and this seems to suggest that $\mathrm{LOH}$ does not occur sequentially but independently (32). In this study, the RCC85\#21 cell proteome was characterized by $2 \mathrm{DE}$ combined with mass spectrometry analysis (MALDI-TOF/MS). Among an overall total of 250 protein spots, 119 spots were identified corresponding to 99 different proteins (not redundant). Multiple spots on the gel identified the same protein, suggesting that different isoforms for the same protein were present, probably due to post-translational protein modifications. In literature, several proteomic maps of kidney tumor cell lines have been drawn (33-36), but none for an immunogenic cell line. The results obtained in this study show that several of the proteins identified have already been described in the literature as characteristic of RCC proteins $(37,38)$. However, several others have still to be defined. Protein analysis using NCBI and SWISS-PROT functional annotation showed enrichment of many cancerrelated biological processes and pathways such as oxidative phosphorylation and glycolysis pathways.

Functional analysis by IFN- $\gamma$-ELISPOT assay confirmed that the RCC85\#21 clone immunogenicity was able to induce high $\mathrm{CD}^{+} \mathrm{T}$ cells reactivity in a predominantly class I-restricted manner. The cytotoxicity tests showed that activated $\mathrm{CD}^{+}$ lymphocytes have a high capacity to lyse the autologous cell line RCC85\#21. In vitro experiments demonstrated a high immunogenicity of the RCC85\#21 clone, although the tumor antigens expressed by renal cells have not yet been identified.

The RCC85\#21 cell line represents an immunogenic cell line suitable for immune stimulation. The identification of novel TAAs by the proteomic approach will allow the evaluation of the immune response in vitro and, subsequently, in vivo, paving the way for new immunotherapeutic strategies in the RCC setting.

\section{Acknowledgements}

We thank Dr Grazia Bortone, Marta Centra and Roberto D'Amore for their technical support and fruitful discussion. This study was supported by Progetto Strategico Regione Puglia grant (E.R., 2008), Ministero dell'Istruzione, dell'Università e della Ricerca (MIUR) FIRB, CAROMICS grant (E.R., 2011).

\section{References}

1. Mydlo JH: Growth factors and renal cancer: Characterization and therapeutic implications. World J Urol 13: 356-363, 1995.

2. Cohen HT and McGovern FJ: Renal-cell carcinoma. N Engl J Med 353: 2477-2490, 2005.

3. Dutcher JP, Mourad WF and Ennis RD: Integrating innovative therapeutic strategies into the management of renal cell carcinoma. Oncology 26: 526-530, 532, 534, 2012.

4. Shablak A, Hawkins RE, Rothwell DG and Elkord E: T cell-based immunotherapy of metastatic renal cell carcinoma: Modest success and future perspective. Clin Cancer Res 15: 6503-6510, 2009.
5. Pate PH, Chaganti RSK and Motzer RJ: Target therapy for metastatic renal cell carcinoma. Br J Cancer 94: 914-919, 2006.

6. Singer EA, Gupta GN and Srinivasan R: Update on targeted therapies for clear cell renal cell carcinoma. Curr Opin Oncol 23: 283-289, 2011.

7. Finke J, Kierstead LS, Ranieri E and Storkus WJ: Immunologic response to RCC. In: Renal Cell Carcinoma: Molecular Biology, Immunology and Clinical Management. Bukowski RM and Novick AC (eds). Humana Press, pp39-62, 2000.

8. McDermott DF: Immunotherapy of metastatic renal cell carcinoma. Cancer 115 (Suppl): 2298-2305, 2009.

9. Fregni G, Perier A, Pittari G, Jacobelli S, Sastre X, Gervois N, Allard M, Bercovici N, Avril MF and Caignard A: Unique functional status of natural killer cells in metastatic stage IV melanoma patients and its modulation by chemotherapy. Clin Cancer Res 17: 2628-2637, 2011.

10. Ward DG, Cheng Y, N'Kontchou G, Thar TT, Barget N, Wei W, Billingham LJ, Martin A, Beaugrand M and Johnson PJ: Changes in the serum proteome associated with the development of hepatocellular carcinoma in hepatitis C-related cirrhosis. Br J Cancer 94: 287-292, 2006.

11. Adam BL, Qu Y, Davis JW, Ward MD, Clements MA, Cazares LH, Semmes OJ, Schellhammer PF, Yasui Y, Feng Z, et al: Serum protein fingerprinting coupled with a pattern-matching algorithm distinguishes prostate cancer from benign prostate hyperplasia and healthy men. Cancer Res 62: 3609-3614, 2002.

12. Pawlik TM, Hawke DH, Liu Y, Krishnamurthy S, Fritsche H, Hunt KK and Kuerer HM: Proteomic analysis of nipple aspirate fluid from women with early-stage breast cancer using isotopecoded affinity tags and tandem mass spectrometry reveals differential expression of vitamin $\mathrm{D}$ binding protein. BMC Cancer 6: 68, 2006.

13. Li J, Zhang Z, Rosenzweig J, Wang YY and Chan DW: Proteomics and bioinformatics approaches for identification of serum biomarkers to detect breast cancer. Clin Chem 48: 1296-1304, 2002.

14. Mueller J, von Eggeling F, Driesch D, Schubert J, Melle C and Junker K: ProteinChip technology reveals distinctive protein expression profiles in the urine of bladder cancer patients. Eur Urol 47: 885-893, discussion 893-894, 2005.

15. Chen YD, Zheng S, Yu JK and Hu X: Artificial neural networks analysis of surface-enhanced laser desorption/ionization mass spectra of serum protein pattern distinguishes colorectal cancer from healthy population. Clin Cancer Res 10: 8380-8385, 2004.

16. Poon TC, Sung JJ, Chow SM, Ng EK, Yu AC, Chu ES, Hui AM and Leung WK: Diagnosis of gastric cancer by serum proteomic fingerprinting. Gastroenterology 130: 1858-1864, 2006.

17. Yang SY, Xiao XY, Zhang WG, Zhang LJ, Zhang W, Zhou B, Chen G and He DC: Application of serum SELDI proteomic patterns in diagnosis of lung cancer. BMC Cancer 5: 83, 2005.

18. Zhang Z, Bast RC Jr, Yu Y, Li J, Sokoll LJ, Rai AJ, Rosenzweig JM, Cameron B, Wang YY, Meng XY, et al: Three biomarkers identified from serum proteomic analysis for the detection of early stage ovarian cancer. Cancer Res 64: 5882-5890, 2004.

19. Raimondo F, Salemi C, Chinello C,Fumagalli D, Morosi L, Rocco F, Ferrero S, Perego R, Bianchi C, Sarto C, et al: Proteomic analysis in clear cell renal cell carcinoma: Identification of differentially expressed protein by 2-D DIGE. Mol Biosyst 8: 1040-1051, 2012.

20. Valera VA, Li-Ning-T E, Walter BA, Roberts DD, Linehan WM and Merino MJ: Protein expression profiling in the spectrum of renal cell carcinomas. J Cancer 1: 184-196, 2010.

21. Sun CY, Zang YC, San YX, Sun W and Zhang L: Proteomic analysis of clear cell renal cell carcinoma. Identification of potential tumor markers. Saudi Med J 31: 525-532, 2010.

22. Fuhrman SA, Lasky LC and Limas C: Prognostic significance of morphologic parameters in renal cell carcinoma. Am J Surg Pathol 6: 655-663, 1982.

23. Kausche S, Wehler T, Schnürer E, Lennerz V, Brenner W, Melchior S, Gröne M, Nonn M, Strand S, Meyer R, et al: Superior antitumor in vitro responses of allogeneic matched sibling compared with autologous patient $\mathrm{CD} 8^{+} \mathrm{T}$ cells. Cancer Res 66: 11447-11454, 2006.

24. Boland CR, Thibodeau SN, Hamilton SR, Sidransky D, Eshleman JR, Burt RW, Meltzer SJ, Rodriguez-Bigas MA, Fodde R, Ranzani GN, et al: A National Cancer Institute Workshop on Microsatellite Instability for cancer detection and familial predisposition: Development of international criteria for the determination of microsatellite instability in colorectal cancer. Cancer Res 58: 5248-5257, 1998.

25. Shevchenko A, Wilm M, Vorm O and Mann M: Mass spectrometric sequencing of proteins silver-stained polyacrylamide gels. Anal Chem 68: 850-858, 1996. 
26. Sugimura J, Tamura G, Suzuki Y and Fujioka T: Allelic loss on chromosomes $3 \mathrm{p}, 5 \mathrm{q}$ and $17 \mathrm{p}$ in renal cell carcinomas. Pathol Int 47: 79-83, 1997.

27. Siu KW, DeSouza LV, Scorilas A, Romaschin AD, Honey RJ, Stewart R, Pace K, Youssef Y, Chow TF and Yousef GM: Differential protein expressions in renal cell carcinoma: New biomarker discovery by mass spectrometry. J Proteome Res 8: 3797-3807, 2009.

28. Cohan CS, Welnhofer EA, Zhao L, Matsumura F and Yamashiro S: Role of the actin bundling protein fascin in growth cone morphogenesis: Localization in filopodia and lamellipodia. Cell Motil Cytoskeleton 48: 109-120, 2001.

29. Sarto C, Marocchi A, Sanchez JC, Giannone D, Frutiger S, Golaz O, Wilkins MR, Doro G, Cappellano F, Hughes G, et al: Renal cell carcinoma and normal kidney protein expression. Electrophoresis 18: 599-604, 1997.

30. Atkins D, Lichtenfels R and Seliger B: Heat shock proteins in renal cell carcinomas. Contrib Nephrol 148: 35-56, 2005.

31. Oizumi S, Strbo N, Pahwa S, Deyev V and Podack ER: Molecular and cellular requirements for enhanced antigen cross-presentation to CD8 cytotoxic T lymphocytes. J Immunol 179: 2310-2317, 2007.

32. Chen M, Ye Y, Yang H, Tamboli P, Matin S, Tannir NM, Wood CG, $\mathrm{Gu} \mathrm{J}$ and $\mathrm{Wu} \mathrm{X}$ : Genome-wide profiling of chromosomal alterations in renal cell carcinoma using high-density single nucleotide polymorphism arrays. Int J Cancer 125: 2342-2348, 2009.
33. Seliger B, Lichtenfels R and Kellner R: Detection of renal cell carcinoma-associated markers via proteome- and other 'ome'based analyses. Brief Funct Genomics Proteomics 2: 194-212, 2003.

34. Perego RA, Bianchi C, Corizzato M, Eroini B, Torsello B, Valsecchi C, Di Fonzo A, Cordani N, Favini P, Ferrero S, et al: Primary cell cultures arising from normal kidney and renal cell carcinoma retain the proteomic profile of corresponding tissues. J Proteome Res 4: 1503-1510, 2005.

35. Craven RA, Stanley AJ, Hanrahan S, Dods J, Unwin R, Totty N, Harnden P, Eardley I, Selby PJ and Banks RE: Proteomic analysis of primary cell lines identifies protein changes present in renal cell carcinoma. Proteomics 6: 2853-2864, 2006.

36. Nakamura K, Yoshikawa K, Yamada Y, Saga S, Aoki S, Taki T, Tobiume M, Shimazui T, Akaza H and Honda N: Differential profiling analysis of proteins involved in anti-proliferative effect of interferon-alpha on renal cell carcinoma cell lines by protein biochip technology. Int J Oncol 28: 965-970, 2006.

37. Hwa JS, Park HJ, Jung JH, Kam SC, Park HC, Kim CW, Kang KR, Hyun JS and Chung KH: Identification of proteins differentially expressed in the conventional renal cell carcinoma by proteomic analysis. J Korean Med Sci 20: 450-455, 2005.

38. Atrih A, Mudaliar M A V, Zakikhani P, Lamont DJ, Huang JT-J, Bray SE, Barton G, Fleming S and Nabi G: Quantitative proteomics in resected renal cancer tissue for biomarker discovery and profiling. Br J Cancer 110: 1622-1633, 2014. 